\title{
As representações sociais do policiamento ostensivo: uma análise da atividade policial militar no contexto de Belo Horizonte
}

\author{
Juracy Costa Amaral \\ Orientador: Maria Stela Grossi Porto \\ Tese de Doutorado \\ Data da defesa: 01.06.2012
}

$\mathrm{N}$

esta tese, discute-se o policiamento ostensivo no contexto de Belo Horizonte, tomando como base as representações sociais produzidas pela população entrevistada em duas regiões desse município. Analisam-se os aspectos institucionais, a imagem e o desempenho policial para compreender os sentidos e significados que a polícia tem para essa população. A Polícia Militar de Minas Gerais é uma instituição pública que, desde a época colonial, tem-se destacado como força repressiva no território mineiro. Cabe-lhe o policiamento ostensivo, mas já auxiliou o Exército brasileiro na guerra do Paraguai, na Era Vargas e no golpe militar da década de 1960. Na segunda metade da década de 1990, os praças dessa corporação fizeram eclodir uma rebelião que teve repercussão nacional e trouxe ao debate a questão do sistema de segurança pública brasileiro. As preocupações com a delinquência e o interesse em compreender como a população belo-horizontina percebe e representa o policiamento militar na região pesquisada fizeram originar este estudo sociológico, que trata de compreender e explicar o policiamento ostensivo com base nas representações sociais produzidas pela população pesquisada. A tese está desenvolvida em duas partes: na primeira, trata-se das fundamentações teóricas e constituição das policiais nas sociedades; na segunda, das considerações analíticas e interpretações dos dados obtidos com a pesquisa empírica. Conclui-se que a população representa a polícia como principal meio de combate à delinquência. Apesar de o seu papel ser pouco compreendido pela população pesquisada, as representações apontam que os segmentos pesquisados confiam na polícia e refletem uma boa imagem da instituição policial, como bem capacitada e treinada, porém, admitem que o policiamento é insuficiente para combater a criminalidade. Considera-se, também, que o problema da falta de policiamento, nos locais onde há ocorrências de crimes, e a demora no atendimento das chamadas constituem as principais deficiências do policiamento e o motivo da incidência criminal, principalmente de furtos, roubos e assaltos.

Palavras-chave: Policiamento Ostensivo, Polícia Militar, Representação Social, Delinquência, Belo Horizonte. 